Executive Summary: Metro Chicago Presbyterian - Jewish Relations “... In Our Time” Presbytery of Chicago, November 2015

The purpose of this document is to provide a theological and relational framework for the Presbytery of Chicago to pursue an engaged and constructive relationship with the Jewish community in metropolitan Chicago (city of Chicago and suburbs). Our spiritual kinship with the Jewish community is not dependent upon a resolution of the Israeli-Palestinian conflict, nor does it presume to offer a specific path to its resolution. Rather, it seeks to provide a framework by which Jews and Presbyterians can discuss the conflict in an engaged, civil, and productive way.

\section{An Understanding in Our Time}

Inspired by the Second Vatican Council's Nostra Aetate declaration issued nearly fifty years ago, we believe God calls us "in our time" to declare a self-understanding of the deep and continuing relationship between congregations of the Presbytery of Chicago and the Jewish community in metropolitan Chicago. In light of this, we propose today that:

- Presbyterian Christians and Jews, each in their own unique way, offer a contemporary witness to the living God of Abraham and Sarah;

- Presbyterians better understand themselves as Christians when they understand the historic and living tradition of the Jewish people;

- Given our shared vision for social justice Presbyterian Christians and Jews have worked together in the past, and in the present continue to work, to strengthen the democratic social contract in the United States consistent with the commandments and values of both traditions; and

- Presbyterian Christians need a theological and relational framework in which to work out our understanding of the sacred promise and hope embodied in ancient Israel in relationship to the modern state of Israel.

For these reasons, we offer this theological affirmation and vision for relations between Presbyterian Christians and Jews in metropolitan Chicago 'in our time.'

\section{A Theological Affirmation}

Over the past fifty years, the Presbyterian Church (USA) has begun to more fully acknowledge its relationship to the modern Jewish people and Judaism. This has been reflected in a variety of denominational confessional and study documents that can offer guidance for the denomination:

- The Confession of 1967

- A Theological Understanding of the Relationship between Christians and Jews (1987)

- The Study Catechism (1998)

- Christians and Jews: People of God (2014)
The Christian church arose within (the people) Israel.

The followers of Jesus remained at first within the people of Israel.

As persons from all nations joined them, they... separated from the Jewish community.

Yet they continued to accept Israel's story as their own and to consider themselves part of the people of God.

We can never lay exclusive claim to being God's people, as though we had replaced those to whom the covenant, the law, and the promises belong.

We affirm that God has not rejected God's people the Jews.

The Lord does not take back the Lord's promises.

We Christians have often rejected Jews throughout our history with shameful prejudice and cruelty.

God calls us to dialogue and cooperation that do not ignore our real disagreements, yet proceed in mutual respect and love.

We are bound together with them in (a) story of those chosen to serve and proclaim the living God.

1977 Declaration of Faith 
In our present day, as Presbyterians, can we see the need to affirm, positively and proactively, our present spiritual kinship with the Jewish people, to rediscover the Jewish dimension of our own tradition, and to engage with the Jewish people in causes of mutual concern?

\section{Changing Hearts and Lives}

Many Presbyterians have become aware of previous strains of anti-Judaic thought present in the way we ourselves sometimes speak and write. Historically, this has been specifically reflected in the Presbyterian tradition, including in the Book of Confessions 5.019 and in the writings of Calvin, Friedrich

Schleiermacher, and Karl Barth. Changing our hearts and lives, which is the essence of repentance, requires us to look critically at Christian beliefs and practices regarding evangelism and our Jewish neighbors, friends, and relatives.

\section{Forging a Framework on 'the Land'}

For Presbyterians, and many but not all Jews, the answer to the question of Jewish sovereignty is to be found in distinguishing the biblical meaning of the land for the chosen people of God from the national aspirations of the modern Jewish people.

Critique of the policies and practices of the state of Israel on political grounds, employing frameworks and criteria used broadly by the international community - and which resonate with the underlying principles of Reformed theology — is an effective way for Presbyterians to enter into this complex discussion. This is in contrast, for example, to the out-of-context use of explicit covenantal warnings embedded in biblical sources and addressed to ancient Israel. In this way, Presbyterians can fully engage questions of justice and peace without resorting to more problematic approaches that slip over into anti-Semitic or anti-Judaic rhetoric or lines of argumentation.

Given this overall framework, Presbyterians can do the following:

- Fully engage in public witness, discourse and action with regards to matters such as self-determination, human rights, reconciliation, justice and peace, related to the Israeli-Palestinian conflict;

- Affirm the aspirations for, and the right to, self-determination by both Israelis and Palestinians;

- Affirm the necessity of human and civil rights afforded to all Arab and other minorities in the state of Israel, and to Jewish and other minorities in a future state of Palestine and other Arab countries;

- Actively work on behalf of Israelis and Palestinians, and a just and peaceful future for both, without compromising our relationship to each people.

\section{Living Together as Covenant Peoples}

Together, Presbyterians and Jews can:

- Share the most treasured aspects of our religious identity

- Work for the well-being of our world

- Create safe havens for religious diversity

This is an invitation to respect and love that does not require us to ignore our real disagreements, but which does require us to do the hard work of building trust and deepening relationship. Pursuing and fostering relationships in these ways carries us into a deeper experience of our own faith commitments. 


\title{
“... in our time..." \\ A statement on relations between the Presbytery of Chicago and the Jewish community in metropolitan Chicago
}

\author{
Proposed to the Presbytery of Chicago
}

November 21, 2015

\section{Purpose}

The purpose of this document is to provide a theological and relational framework for the Presbytery of Chicago to pursue an engaged and constructive relationship with the Jewish community in metropolitan Chicago (city of Chicago and suburbs).

\section{Rationale}

As Christians, Presbyterians are ever aware that our theological convictions inform and guide our attitudes and practices, just as the practices of our faith embody our beliefs and convictions. We place a high value on theological understanding as reflected in our Book of Confessions, standards for ordination to church office, Christian education, and in our discourse, deliberations and actions as a corporate body.

Therefore, in light of historic circumstances and current realities that the Jewish community has endured and continues to face, we seek to renew our theology and practices with fresh insights of God's Word to us in Jesus Christ as witnessed by Holy Scripture interpreted in the power of the Spirit.

\section{Process}

This document, presented to the Presbytery Assembly by the Ecumenical and Interreligious Work Group, has been vetted for review and comment by: Christian and Jewish scholars; members, congregations and other groups within Chicago Presbytery; and similar counterparts in other presbyteries of the Presbyterian Church (USA).

A draft of the document received a 'first reading' by the Presbytery Assembly at its June 16, 2015 meeting.

Motion: $\quad$ The Presbytery of Chicago adopt the “... in our time...” A statement on relations between the Presbytery of Chicago and the Jewish community in metropolitan Chicago, for the following purposes:

To serve as a statement on the relationship of Chicago Presbytery with the Jewish community in metropolitan Chicago;

To serve as affirmation to the Jewish community of our spiritual kinship with them, and a commitment to an active and deepening relationship;

To serve as a source of study, guidance and inspiration for local congregations and for the Presbytery as a whole in their dialogue and engagement with the Jewish community in metropolitan Chicago. 


\section{Preface}

During a time of much needed renewal, as deep disagreement and polarizing discourse over the ongoing Israeli - Palestinian conflict has led to fractured relations between Presbyterians within the denomination, and between the denomination and the Jewish community across their local and national expressions, we seek to reconsider our theology and practices. In light of historic circumstances and fresh insights of how the God we know in Jesus Christ is at work among us, we cannot consider our relationship with the Jewish community in the US without taking this reality into account.

Further, it must be clearly stated that the affirmation of our spiritual kinship with the Jewish community is not dependent upon a resolution of the Israeli-Palestinian conflict, nor does it presume to offer a specific path to its resolution. Rather, it seeks to provide a framework by which Jews and Presbyterians can discuss the conflict in an engaged, civil, and productive way.

This document is primarily addressed to Presbyterians, in the Presbytery of Chicago, for the purpose of framing and guiding individual and corporate discourse, dialogue, relations and action with respect to the Jewish community in metropolitan Chicago. We recognize the pluralistic reality and diversity of the members of the body of the PC(USA), the Presbytery of Chicago, and the individual congregations therein.

As this document addresses the relationship of Presbyterians to the Jewish people in metropolitan Chicago, and as such will be 'overheard' by the Jewish community, we strive to understand the Jewish community as they understand themselves, and to be clear about our commitment to the wellbeing and aspirations of the Jewish people. We recognize the pluralistic reality and diversity of the Jewish people in metropolitan Chicago, in the United States, and around the world.

Any credible document that addresses the relationship of Presbyterians to the Jewish people must take into account the Israeli - Palestinian conflict, and as such will be 'overheard' by the Palestinian community in metropolitan Chicago. For that reason, we also strive to be clear about our commitment to the wellbeing and aspirations of the Palestinian people.

It is the hope of the Ecumenical and Interreligious Work Group that this document might be a resource to other presbyteries and the Presbyterian Church (USA) in their broader relations with the Jewish community in the US. 


\section{Preamble}

....In everlasting love,

the God of Abraham and Sarah chose a covenant people to bless all families of the earth.

Hearing their cry,

God delivered the children of Israel

from the house of bondage...

Loving us still,

God makes us heirs with Christ of the covenant.

like a father who runs to welcome the prodigal home,

God is faithful still.... (10.3)

\section{(A Brief Statement of Faith 1990, 10.3)}

The Christian church arose within (the people) Israel.

The followers of Jesus

remained at first within the people of Israel.

As persons from all nations joined them, they...separated from the Jewish community.

Yet they continued to accept Israel's story as their own and to consider themselves part of the people of God.

We can never lay exclusive claim to being God's people, as though we had replaced those

to whom the covenant, the law, and the promises belong.

We affirm that God has not rejected God's people the Jews.

The Lord does not take back the Lord's promises.

We Christians have often rejected Jews throughout our history with shameful prejudice and cruelty.

God calls us to dialogue and cooperation that do not ignore our real disagreements, yet proceed in mutual respect and love.

We are bound together with them in (a) story of those chosen to serve and proclaim the living God.

\section{(1977 Declaration of Faith) ${ }^{1}$}




\section{An Understanding in Our Time}

Nearly fifty years ago, the Second Vatican Council issued a groundbreaking declaration on the relation between the Roman Catholic Church and the wider Christian Church, and with other non-Christian religious communities, especially the Jewish community. Titled Nostra Aetate (meaning literally 'in our time') it spoke of an emerging reality when "... day by day humankind is being drawn closer together, and the ties between different peoples are becoming stronger..." in light of which "...the Church examines more closely her relationship to non-Christian religions." Given the task of the Church in "...promoting unity and love among humankind, indeed among nations..." it was crucial to consider "... what human beings have in common and what draws them into fellowship."

While addressed in general to all the non-Christian religions, Nostra Aetate nevertheless paid special attention to the relations of Christians and Jews, affirming that "...God holds the Jews most dear for the sake of their Fathers..." and decrying "...hatred, persecutions, displays of anti-Semitism, directed against Jews at any time and by anyone."

We believe God calls us "in our time" to declare a self-understanding of the deep and continuing relationship between congregations of the Presbytery of Chicago and the Jewish community in metropolitan Chicago. Considering the tragedy of the Holocaust, the establishment of the state of Israel, and the rediscovery (through historical-critical inquiry) of the Jewish covenantal dimension of our Reformed faith, we propose today that:

- Presbyterian Christians and Jews, each in their own unique way, offer a contemporary witness to the living God of Abraham and Sarah;

- Presbyterians understand themselves better as Christians when they understand the historic and living tradition of the Jewish people;

- Given our shared vision for social justice Presbyterian Christians and Jews have worked together in the past, and in the present continue to work, to strengthen the democratic social contract in the United States consistent with the commandments and values of both traditions;

- Presbyterian Christians need a theological and relational framework in which to work out our understanding of the sacred promise and hope embodied in ancient Israel in relationship to the modern state of Israel. This framework is also crucial to our understanding of the ways in which that sacred promise and hope remains pivotal to the evolving identity of the US Jewish community today, as they understand themselves.

For these reasons, we offer this theological affirmation and vision for relations between Presbyterian Christians and Jews in the United States 'in our time.' 


\section{A Theological Affirmation}

Over the past fifty years, the Presbyterian Church (USA) has begun to more fully acknowledge its relationship to the modern Jewish people and Judaism. This has been reflected in a variety of denominational confessional and study documents that can offer guidance for the denomination:

The Confession of 1967: In this confession, Presbyterians expressed the significant statement that Jesus was indeed not just human, but "a Palestinian Jew" (9.08) living amongst his people, Israel, "whom God chose to be his covenant people to serve God in love and faithfulness (9.18)". Of significance to this confession is the fact that Jesus indeed came "out of Israel." (9.19)

A Theological Understanding of the Relationship Between Christians and Jews (1987): This General Assembly approved study document highlighted seven theological affirmations regarding Christianity and its relationship with Judaism:

1 That Christians and Jews worship the same God.

2 That Christian identity is intimately related to the continuing identity of the Jewish people.

3 That Jews and Christians share an elect status to be a light to the nations.

4 That Jews are in continual covenant with God and are therefore partners and to be treated as such.

$5 \quad$ A pledge by Christians to put an end to "the teaching of contempt" toward Jews.

6 An obligation for Christians to discern the existential importance of the land within Judaism and its repercussions for Christian theology.

7 A readiness to act with Jews in promotion of the shared hope of a peaceable kingdom.

The Study Catechism (1998): With significance for the Christian relationship with Jewish tradition and religion, the following developments can be noted in this approved Presbyterian teaching resource:

1 The lifting up of the Ten Commandments as a source of "God's law" for our lives, which should be followed out of gratitude (Question 89-92).

2 The reaffirmation of the covenant relationship between God and (the people) Israel, stating that "God has not rejected Israel, that God still loves Israel, and that God is their hope, "for the gifts and the calling of God are irrevocable" (Rom 11:29). (Question 37)

3 The necessity of a Christian's vigilant stance against "prejudice of people who belong to any vulnerable, different or disfavored social group", specifically lifting up "Jews" as among those who have "suffered terribly from being subjected to the slurs of social prejudice."(Question 115) 
Christians and Jews: People of God (2014): A recent General Assembly approved resource regarding Jewish/Christian relations highlights the following significant developments for Presbyterians:

- A rejection of any theology that attempts to see the Jewish people as supplanted or replaced by Christians as "contrary to the core witness of the New Testament and ... not supported by the mainstream Reformed tradition."

- A refutation of anti-Judaic rhetoric in the New Testament as appropriate for current conversation and dispute with Jews.

- An affirmation of the existential importance of the land of Israel as "particular and concrete" for Jews, but also not sufficient "to resolve this conflict or provide any basis by which to settle modern territorial disputes," affirming that a Christian theology of the land must "base [its] commitments on a justice for all peoples."

- A continual recognition that Jews and Christians are "partners in hope" and should view and treat each other accordingly.

In our present day, as Presbyterians, can we see the need to affirm, positively and proactively, our present spiritual kinship with the Jewish people, to rediscover the Jewish dimension of our own tradition, and to engage with the Jewish people in causes of mutual concern?

Jesus sought the well being of the Jewish people, and through this, the renewal of the world. By following the teaching and practice of Jesus, Presbyterians not only 'love our neighbor as ourselves', but fulfill God's call to discipleship which comes through him. In this context, a Reformed theology of Presbyterian relations with the Jewish people...

- Humbles Christians as we are reminded that we are not alone in the sacred story of salvation;

- Reminds the Church of the witness of God's plan for all people through the existence, integrity, and perseverance of Israel as a unique covenantal people, called to be 'light of the world' and a 'blessings to the nations;'

- Preserves the Jewish roots and context of which Jesus was a part;

- Grounds Christian theological reflection on 2,000 years of a dynamic and vital Jewish civilization, which continues to this day with the independent and changing lives of a real and living Jewish people;

- Provokes the church to repentance from the hubris and historic contempt and actions towards the Jewish people;

- Sustains a transformative partnership even when there is irreconcilable disagreement about messianic fulfillment (in Jesus of Nazareth) or a yet unrealized expectation for a messianic age (full realization of God's promises to the people Israel and with it the world);

- Gives witness to the One God, to the commandments, and to the ethics that flow from them; 
- Awakens Christians to the evolving nature of our understanding of God's activity by learning the history of the people Israel in its historic and modern embodiments.

\section{Changing Hearts and Lives}

\section{A. Owning our Historical Privilege}

As with our Catholic brothers and sisters from fifty years ago, in the last several years conversations with Jews have renewed our concern to guard against anti-Semitism and anti-Jewish motifs and stereotypes. Many Presbyterians have become aware of previous strains of anti-Judaic thought present in the way we ourselves sometimes speak and write, and of the ways in which the classic medieval teaching of contempt of Judaism and the Jewish people continues to live on in contemporary expressions of anti-Semitic rhetoric:

"We acknowledge in repentance the church's long and deep complicity in the proliferation of antiJewish attitudes and actions through its 'teaching of contempt' for the Jews. Such teaching we now repudiate, together with the acts and attitudes which it generates" (from 'A Theological Understanding of the Relationship Between Christians and Jews,' 1987).

Historically, this has been more specifically reflected in the Presbyterian tradition...

- In the condemnation found in the Second Helvetic Confession (1566), under "HERESIES" regarding the doctrine of God: "...Therefore we condemn the Jews and Mohammedans, and all those who blaspheme that sacred and adorable Trinity" (Book of Confessions 5.019).

- In his controversies with Roman Catholic writers and Michael Servetus, the attacks of Calvin on “...Scripture exegesis which indulges in materialistic or 'carnal' interpretations, a pattern Calvin frequently identifies as typically Jewish" (Mary Sweetland Laver, "Calvin, Jews, and intra-Christian Polemics," <Ph.D. diss., Temple University, 1988>, 224).

- In the assessment of Friedrich Schleiermacher, the Prussian Reformed theologian who was one of the founders of Protestant liberal theology, who wrote in 1799 that "Judaism is long since a dead religion, and those who at present still bear its colors are actually sitting and mourning beside the undecaying mummy and weeping over its demise and sad legacy" (in On Religion: Speeches to its Cultured Despisers, Richard Crouter, trans. <New York: Cambridge Univ. Pr., 1996>, 113-14).

- In the admission of Karl Barth, who, though opposed to the Nazis and attentive to a "doctrine of (the people) Israel" in his theology, admitted that "... in personal encounters with living Jews (even Jewish Christians) I have always, so long as I can remember, had to suppress a totally irrational aversion..." which "...could have had a retrogressive effect on my doctrine of Israel" (Karl Barth: Letters 19611968, ed. J. Fangmeier and H. Stoevesandt; trans. and ed. G. W. Bromily < Grand Rapids, MI: Eerdmans, 1981>, 262).

- In the Barmen Declaration of May 1934 (included in our Book of Confessions), Barth and the other 'Confessing Church' leaders issued the admonition to resist the influence of Nazi ideology promoted by the movement of "German Christians" in the churches. Nevertheless, the Declaration was silent about the mistreatment of Jews and defamation of Judaism, and the racist intentions of Nazi anti-Semitism. 


\section{B. Our Commitment to Change}

In light of this history, and ongoing spiritual kinship with Jewish people, we must recommit ourselves to more accurate biblical and theological scholarship and Christian education in all our congregations and institutions regarding the treatment of Jews, Judaism, and the history of God's relation with the Jewish people in the past and present. This includes scrutinizing our curriculae in congregations and seminaries to discover where we may be communicating 'false witness' about Jews and Judaism. The more comprehensive our study of this covenantal people, the safer the lives of the Jews, and the practice of their way of life, will be in our local communities.

Unfortunately, the attitudes and beliefs of the church toward the Jewish people and Judaism have often been woefully inadequate-not acknowledging the impact of the Jewish dimension of New Testament witness, nor the significance of the inclusion of the Hebrew Scriptures in the Christian canon. Supersessionist theology (seeking to replace the Jewish covenant with the Christian covenant), and the persistence of anti-Judaic rhetoric in Christian thought (holding contempt for the Jewish character of biblical revelation) are painful examples of these attitudes and beliefs that have often led to tragic consequences.

We must seek unambiguously respectful forms of attribution and dialogue between Jews and Presbyterians. "God calls us to dialogue and cooperation that do not ignore our real disagreements, yet proceed in mutual respect and love. We are bound together with them in a...story of those chosen to serve and proclaim the living God” (from 'A Declaration of Faith', 1976, 1977).

Changing our hearts and lives - which is the essence of repentance - also requires us to look critically at Christian beliefs and practices regarding evangelism and our Jewish neighbors, friends, and relatives. One of our study documents states frankly:

"We must continue to be clear that proselytism by Christians seeking to persuade, even convert, Jews often implies a negative judgment on Jewish faith. Jewish reluctance to accept Christian claims is all the more understandable when it is realized that conversion is often seen by them as a threat to Jewish survival, as many Jews who unite with the church sever their bonds with their people" (from 'A Theological Understanding of the Relationship between Christians and Jews,' 1987).

Our past practices of evangelizing Jews assumed that witness and testimony occurred only in one direction: from Christians to Jews, as if Jews were godless, lacking covenant, in need of conversion to find relationship with God. But this is contrary to Scripture as the 2014 General Assembly study document argues: "The New Testament makes it clear to Christians that Jews are not empty vessels, without God, who must be filled with Christianity to be restored to divine favor.... (Romans 11:1, 11, 28, 31, 33, 36)." The document then affirms:

"God remains faithful to the people Israel; God remains faithful to Christians. Jews remain faithful to the God of Abraham, Isaac, and Jacob; Christians remain faithful to the God of Abraham, Isaac, and Jacob whom we know in Emmanuel, Jesus Christ. As two peoples who are known and loved by God and who know and love the one God, Christians and Jews are therefore called to be faithful to one another in bonds of love" (from 'Christians and Jews: People of God,' p. 16). 
Rather than one-way communication, Presbyterians are called with Jews to a relationship characterized by "mutual witness," "mutual disclosure," "mutual affirmation," and "mutual questioning and correction" (from 'Christians and Jews: People of God,' p. 17). In such a relationship, we will no doubt continue to ponder the ongoing mysteries of election, mission, and 'the promise of the land.' And of those three, the matter of the 'land' looms large at this particular moment in time.

\section{Forging a Framework on 'the Land'}

For Presbyterians, and many but not all Jews, the answer to the question of Jewish sovereignty is to be found in distinguishing the biblical meaning of the land for the chosen people of God from the national aspirations of the modern Jewish people.

On the one hand, these national aspirations for Jews are grounded in the sacred tradition of Israel. Their attachment to 'the land' is deepened by a history of two thousand years of exile and suffering in lands where the Jewish people had no sovereignty; of a longing for a homeland; of the horror of the Holocaust; of the establishment of the modern state of Israel; and of the ongoing struggle over sovereignty with respect to the Palestinian people who know this same land as their homeland.

On the other hand, (to borrow from official Catholic teaching): "The existence of the State of Israel and its political options should be envisaged, not in a perspective which is in itself religious, but in their reference to the common principles of international law." ("Notes on the Correct Way to Present the Jews and Judaism in Preaching and Catechesis in the Roman Catholic Church" 1985). This represents the implications of Nostra Aetate that were worked out extensively in Catholic social teachings, employing international law and broadly recognized human rights to critique the practices and policies of the modern Jewish state, instead of using any theological objection to the Jewish return to sovereignty in the ancient land.

In terms of our spiritual kinship to the Jewish community, it is especially important in our analysis and critique of the Israeli-Palestinian conflict to be vigilant against employing language, rhetoric and lines of argumentation that introduce harmful stereotypes, anti-Jewish motifs, and classic Christian anti-Judaic theology into nevertheless critically necessary discussions.

An example of anti-Judaic theology is the notion that with the coming of Christ, the Jews lost connection to 'the land' and their covenant with God, as expressed in a variety of Christian writings, such as Martin Luther (1483-1546) in his Interpretation of Psalm 2: "Finally they were exterminated and devastated by the Romans over fourteen hundred years ago - so that they might well perceive that God did not regard, nor will regard, their country, city, temple, priesthood, or principality, and view them on account of these as his own peculiar people."

While it is challenging to address the rights and aspirations of both the Jewish and Palestinian peoples, and the steps needed toward a just and peaceful resolution of the Israeli-Palestinian conflict, the conversation and analysis can be engaged frankly and critically without resorting to such language and thought. At the same time, Presbyterians can respectfully communicate that the use of the historical victimization of the Jewish people, in so far as such use seeks to legitimize specific policies and practices regarding the occupation and its impact on the Palestinian people, does not further constructive discourse about the state of Israel. 
Critique of the policies and practices of the state of Israel on political grounds, employing frameworks and criteria used broadly by the international community - and which resonate with the underlying principles of Reformed theology ${ }^{2}$ - is an effective way for Presbyterians to enter into this complex discussion. This is in contrast to the out-of-context use of explicit covenantal warnings embedded in biblical sources and addressed to ancient Israel. In this way, Presbyterians can fully engage questions of justice and peace without resorting to more problematic approaches that slip over into anti-Semitic or anti-Judaic rhetoric or lines of argumentation.

Given this overall framework, Presbyterians can do the following:

- Fully engage in public witness, discourse and action with regards to matters such as self-determination, human rights, reconciliation, justice and peace, related to the Israeli-Palestinian conflict;

- Affirm the aspirations for, and the right to, self-determination by both Israelis and Palestinians;

- Affirm the necessity of human and civil rights afforded to all Arab and other minorities in the state of Israel, and to Jewish and other minorities in a future state of Palestine and other Arab countries;

- Actively work on behalf of Israelis and Palestinians, and a just and peaceful future for both, without compromising our relationship to each people.

\section{Living Together as Covenant Peoples}

Question 52 in The Study Catechism asks, "How should I treat non-Christians and people of other religions?"and then answers this way:

"As much as I can, I should meet friendship with friendship, hostility with kindness, generosity with gratitude, persecution with forbearance, truth with agreement, and error with truth. I should express my faith with humility and devotion as the occasion requires, whether silently or openly, boldly or meekly, by word or by deed. I should avoid compromising the truth on the one hand and being narrow-minded on the other. In short, I should always welcome and accept these others in a way that honors and reflects the Lord's welcome and acceptance of me."

(from Book of Catechisms: Reference Edition <Louisville, KY: Geneva Pr., 2001>, 84).

This is an invitation to respect and love that does not require us to ignore our real disagreements, but which does require us to do the hard work of building trust and deepening relationship. Pursuing and fostering relationships in these ways carries us into a deeper experience of our own faith commitments. The spiritual practice of such kindness, generosity, persistence, humility and open-hearted conviction may help us develop a sense of empathy that in no way negates our sense of self. On the contrary, such spiritual disciplines are a means of developing caring and considerate hearts-helping us to more accurately know and more sincerely love our Jewish neighbors. 
Together, Presbyterians and Jews can share the most treasured aspects of our religious identity:

- By inviting, listening to and offering mutually transparent testimonies.

- By regularly discussing issues that are significant to each community.

- By sharing, through conversation or encounter, ritual practices that are especially meaningful.

\section{Together, Presbyterians and Jews can work for the well being of our world:}

- By coming together to aid yet other religious groups who might face prejudice in their neighborhoods.

- By working together on issues of hunger, violence, poverty, immigration, and other shared concerns for the common good.

\section{Together, Presbyterians and Jews can create safe havens for religious diversity:}

- By building relationships over time, not in reaction to crises, but in order to live out a commitment to deep hospitality and mutual respect.

- By maintaining these relationships even in (and especially in) times of crisis.

- By listening attentively and representing our Jewish dialogue partners in ways that they feel accurately represent them.

With the best elements of our respective traditions, the relationship between Christians and Jews remains unique, foundational and enduring.

Notes

(1) The 1976-77 Declaration of Faith of the Presbyterian Church (US) was never approved as a confessionnal document. It was approved as an educational and liturgical resource, and later accepted by the PC (USA).

(2) Reformed theology sees human collectives, such as a nation state, as an instrument of providence, contributing to human flourishing. At the same time, nation states are fallible, and therefore open to critique and reform. Such a critique can be based, for instance, in the theological claim that all human beings are created in the image of God, and therefore worthy of the respect and recognition accorded them by the central principles found in the United Nations Declaration of Human Rights. Any attempt to sacralize the temporal and fallible nature of the nation state is idolatrous, and ultimately destructive of human well being.

We acknowledge that empires, kingdoms...etc. are ordained by God...for the manifestation of his own glory and for the good and well being of all men [humanity].

Scots Confession XXIV 3.24

We reject the false doctrine, as though the State, over and beyond its special commission, should and could become the single and totalitarian order of human life....

Theological Declaration of Barmen 8.23

Although nations may serve God's purposes in history, the church which identifies the sovereignty of any one nation or any one way of life with the cause of God denies the Lordship of Christ and betrays its calling.

Confession of $1967 \quad 9.45$ 


\section{Resources}

\section{Declarations, Study Papers, and Other Online Documents:}

Nostra Aetate, Declaration on the Relation of the Church to Non-Christian Religions...Proclaimed by His Holiness Pope Paul VI on October 28, 1965, The Second Vatican Council.

(http://www.vatican.va/archive/hist_councils/ii_vatican_council/documents/vat-ii_decl_19651028_nostra-aetate_en.html).

"Notes on the Correct Way to Present the Jews and Judaism in Preaching and Catechesis in the Roman Catholic Church" 1985.

(http://www.vatican.va/roman_curia/pontifical_councils/chrstuni/relations-jews-

docs/rc pc chrstuni doc 19820306 jews-judaism en.html).

A Theological Understanding of the Relationship between Christians and Jews, 1987 Study Paper, Presbyterian Church (USA).

(http://www.pcusa.org/site_media/media/uploads/_resolutions/christians-jews.pdf)

Christians and Jews; People of God. Theology and Worship Church Issues Series No. 7. Louisville, KY:

Presbyterian Mission Agency, 2010.

(http://store.pcusa.org/7042005004).

Interreligious Stance Paper, Presbyterian Church (USA) (2014):

(http://www.pcusa.org/resource/interreligious-stance-adopted-221st-general-assemb/)

\section{Drafting Team}

Rev. Dr. Jay Moses

Pastor, Hope Presbyterian Church, Wheaton

Convener, Ecumenical and Interreligious Work Group

Presbytery of Chicago

Rev. Dr. Robert Cathey

Professor of Theology, McCormick Theological Seminary

Member, Ecumenical and Interreligious Work Group,

Presbytery of Chicago

Rev. Nanette Sawyer

Pastor, St. James Presbyterian Church / Grace Commons

Rev. Dirk Ficca

Director, Interreligious Initiative for Middle East Peace

Presbytery of Chicago

With special thanks to Jill Folan and Katie Rains. 


\section{McCORMICK THEOLOGICAL SEMINARY}

$\begin{array}{llll}\text { FROM: } & \text { Rev. Dr. Robert Cathey } & \text { TO: } & \text { Chicago Presbytery } \\ \text { DATE: } & 9 \text { November } 2015 & \text { RE: } & \text { Process for '....in our time...' }\end{array}$

The Ecumenical \& Inter-Religious Work Group (EIWG) of Chicago Presbytery recognized in 2014 that 28 October 2015 would mark the fiftieth anniversary of the official publication on "...In Our Time...," the Vatican II teaching document that radically revised centuries of Roman Catholic teaching and practice regarding Jews, Judaism, and other religions. “...In Our Time...” impacted Christians, Jews and others around the world and influenced Presbyterians who wrote The Confession of 1967 and other Presbyterian confessional and study documents.

Recognizing the revolution in human relations sparked fifty years ago by “...In Our Time...”, our Work Group created a sub-committee to draft a document for our time in 2015 that might become a resource for our own congregations, institutions, and leaders in our relations with Jews, Jewish leaders, congregations, and institutions in Chicago. On 10 November 2014 (one year ago), we met at McCormick Seminary and began the drafting process.

In winter and spring of 2015 we shared early draft versions of our document for constructive critique with members of our Work Group, with leaders from the Jewish United Federation of Chicago, American Jewish Committee, and Chicago Board of Rabbis, persons with whom we have been in dialogue since September 2004. We shared a draft version with the Christian Scholars Group for Christian - Jewish Relations, an organization founded by the National Council of Churches in 1967 that includes Roman Catholic, Orthodox, Lutheran, United Church of Christ, and Presbyterian scholars and directors of centers for inter-religious relations in the US. I also shared a draft of our document with McCormick students in Introduction to Christian Theology for their critique.

Chicago Presbytery received a draft of “...in our time...” at the 16 June Presbytery Assembly for a first reading. We created a set of discussion questions, divided the Assembly members into small groups, and received oral and written responses from all present, and from other members of Presbytery who wrote us via email afterwards.

I combined all these responses into a detailed report shared with our Work Group later in the summer. Chicago Presbytery also emailed all other PC (USA) Presbyteries with a draft for their comment and we have read those responses via email.

By October we had a new draft that I shared with the Christian Scholars Group meeting at St. Joseph University in Philadelphia and they made detailed comments on all sections.

In light of all the feedback we have received from Presbyterians and others, we have revised some of our indicative statements into interrogative form to invite members of Presbytery into an ongoing dialogue with each other and with our neighbors that will continue beyond our Presbytery Assembly of 21 November.

We give thanks for all persons and organizations that have commented on drafts of this document. We have learned much from your wisdom and deep commitment to the well being of all peoples in our city, our country, and in Israel / Palestine.

We pray the Creator and Redeemer of all things will continue to reform our Presbytery and Church by the Word and Spirit who comes to us in Jesus "...in our time....” 